\title{
Impact of Customer's Impulsivity and Marketing Cues to Purchase Decision of Beverage Product Category
}

\author{
*Desi Ambar Prawono, Mustika Sufiati Purwanegara, Mia Tantri Diah Indriani \\ Bandung Institute of Technology, School of Business and Management, Indonesia \\ 'desiambar@sbm-itb.ac.id
}

\begin{abstract}
The research was conducted to explore consumer impulsivity and impulsive buying toward beverages product. In addition, in subsequent analysis, it also applies Consumer Decision Journey into impulsive buying behavior on beverage products. The analysis explains which marketing cues acts as most influential factors in such purchase behavior. Questionnaire was designed based on valid scale borrowed from previous research. A total of 105 respondents participated in this research. Questionnaire was distributed directly and by electronic mail. Based on the analysis, consumer only exercises impulsive buying on green tea and ready to drink tea category. Past experience and WOM are the most influencing factors in each step of the customer decision journey. Implications of this research are useful for FMCG marketers in improving marketing cues.
\end{abstract}

Keywords: impulsivity, marketing cues, customer decision journey, beverage product

\section{Introduction}

Consumer decision to purchase, in general, can be distinguished into planned and unplanned buying. The frequency of unplanned buying is $90 \%$, with 9 out of 10 customer buying product impulsively Mihic and Kursan (2010). 27-62\% of product purchased is impulsive purchase (Coley, 2002; Mihic and Kursan, 2010). Impulsive buying is indicated with spontaneous and unconsciously buying decision, which usually happens to low involvement products or fast moving consumer goods (FMCG). In many countries, FMCG is target of impulsive buying. Based on its product category, FMCG is divided into personal care, household care, and food beverage. This research is focused on impulsive buying toward beverage category. In this research beverage categories are focused in 13 product groups; ready to drink tea (TRTD), crash tea (TC), green tea (TG), powder coffee (CP), instant coffee (CI), milk containers (MRTD), condensed milk (MC), powdered milk high calcium for adult (MPA), liquid supplement drinks (LS), powdered supplement drink (PS), powdered fruit juice (FJP), isotonic ready to drink (IRTD), and fruit juice ready to drink (FRTD). Preliminary observations were done to explore the impulsive buying behavior around the point of purchase to confirm the beverages purchase during waiting time. This study was conducted in several supermarkets around the cashier area, where there are displays of candies, beverages, and other small-sized products. These displays were meant to encourage impulsive buying among the customers who are in line to pay for their groceries. From the observation, it was discovered that customers tend to take isotonic, bottled tea and easy to drink fruit juice. Therefore, objective of this paper is to investigate how marketing cues influences impulsivity in beverage category. Research questions are, as follow:

1. How consumer's impulsivity influences number of products being consumed?

2. Which of the marketing cues (WOM, store experience, online information search, offline information search, advertising, store displays, sales, and past experience) is the most influential in impulse buying of beverage?

\section{Literature Review}

Definition of unconscious/ impulsive/unplanned buying: Impulsive buying is unplanned purchase made by consumers spontaneously without evaluating the products and learning about the consequences of the purchase Mihic and Kursan (2010). According American Marketing Association (AMA) impulsive buying is a purchase without planning, whereas Ceballos (2009) argued that impulsiveness is a tendency of consumer to buy spontaneously, unreflectively, suddenly, unexpectedly, and kinetically. Factors influencing impulsive 
buying are desire to try new product, advertisement, display and product packaging, persuasion, and attractive offering from the sales. According to previous research (Rook \& Fisher, 1995; Beatty \& Ferrell, 1998; Verplanken \& Herabadi, 2001; Mihic and Kursan, 2010), some characteristics in customer impulsive buying are tendency to be spontaneous, satisfied feeling after, and shopping without list. According to Mittal (1989), there are several focuses in customer's involvement, besides product. There are involvement in decision to purchase, consumption, searching activities and information processing (O'Cass, 2000). Zaichkowsky (1986), Crugman (1965) and Chaudhuri (2006) describe three difference domains of involvement: advertising, product, and purchase decision. That involvement leads someone to collecting various information. Involvement in this research is focused on pre-purchase (initial consideration) until at the moment of purchasing (at the cashier) settings/search activities, information processing, evaluation, and perception of brand differences.

Factors influence toward impulsive buying: Previous research explores situation factors from environment store that influence impulsive buying like visual stimulus from product or advertising. Environment factors in physic store are general design interior (lighting, color, music, aromatic, equipment, etc.); display equipment or tools of store; display product; and point of sale material promotion. Previous research, which is conducted by Ceballos (2010), showed that store atmospheres give excitement and encouragement to shop impulsively. Semuel (2006) argued that impulsive buying gives emotional experience more than rational. Therefore, impulsive buying is considered as irrational decision.

Consumer decision journey: According Bughin and Jorgen (2010) consumer decision journey is divided into initial consideration set, active evaluation, and moment of purchase, in cyclical pattern. Initial consideration is condition when customer before go to store, active evaluation when customer in the store, and moment of purchase when customer at chasier/ready to purchase. In each stage, the stimuli are advertising, previous usage, WOM (word of mouth), shopping, and internet information. Consumers consider various types of brand and other information. If customers are ready to buy but later became dissatisfied during the postpurchase evaluation, there will be a process of brand re-evaluation. The re-evaluation process involves active information search. Various types of marketing cues are introduced on brand communication; reflections on past experiences; consumer driven marketing (WOM , online research, offline and/or print reviews), and the last is the interaction between the sale person and other brand representative. This interaction is critical for brand managers to understand how consumers come into contact with the brand during the whole decision journey (Moon, 2011).

Based on previous research and qualitative study, this research proposes several hypotheses;

H1 : There is significant positive association between numbers of beverage products consumed and customer's impulsivity

H2(a-i) : There is significant positive impact of marketing cues toward purchase decision of beverage categories.

\section{Methodology}

Measurement: The methods used in this study are qualitative and quantitative method. First was qualitative study by doing observations in supermarkets. Second was building questionnaire based on borrowed scale from previous studies such as Weun et al. (1997), Chaudhuri (2005) and Bughin \& Jorgen (2010).

\section{Table 1: Constructs and their sources}

\begin{tabular}{ll}
\hline Constructs & Sources \\
\hline Impulsivity & Weun et al. (1997) \\
Marketing Cues & Bughin \& Jorgen (2010), Chaudhuri (2006), \\
Purchase Behavior & Moon (2011), Chaudhuri (2006) \\
\hline
\end{tabular}

The construct are generated from several previous research (see Table 1.). The indicator of constructs for purchase behaviour use are number of brand consumed, number beverage consumed, satisfaction, loyalty, continuity, feel and think toward the beverage products. For satisfaction, loyalty, continuity, feel, and think toward the beverage products, scale used is 1 (strongly dissatisfaction/ unloyal/not continue/ unimportant) 
until 10 (strongly satisfaction/ loyal/continue/important). The measurement of impulsivity using Weun et al. (1997) scale with Linkert (1932) scales ranging between 1 (strongly disagree), 2 (disagree), 3 (neutral), 4 (agree) and 5 (strongly agree) and consist of 5 item questions.

Figure 1: Conceptual Model for FMCG (adoption from Bughin and Jorgen, 2010)

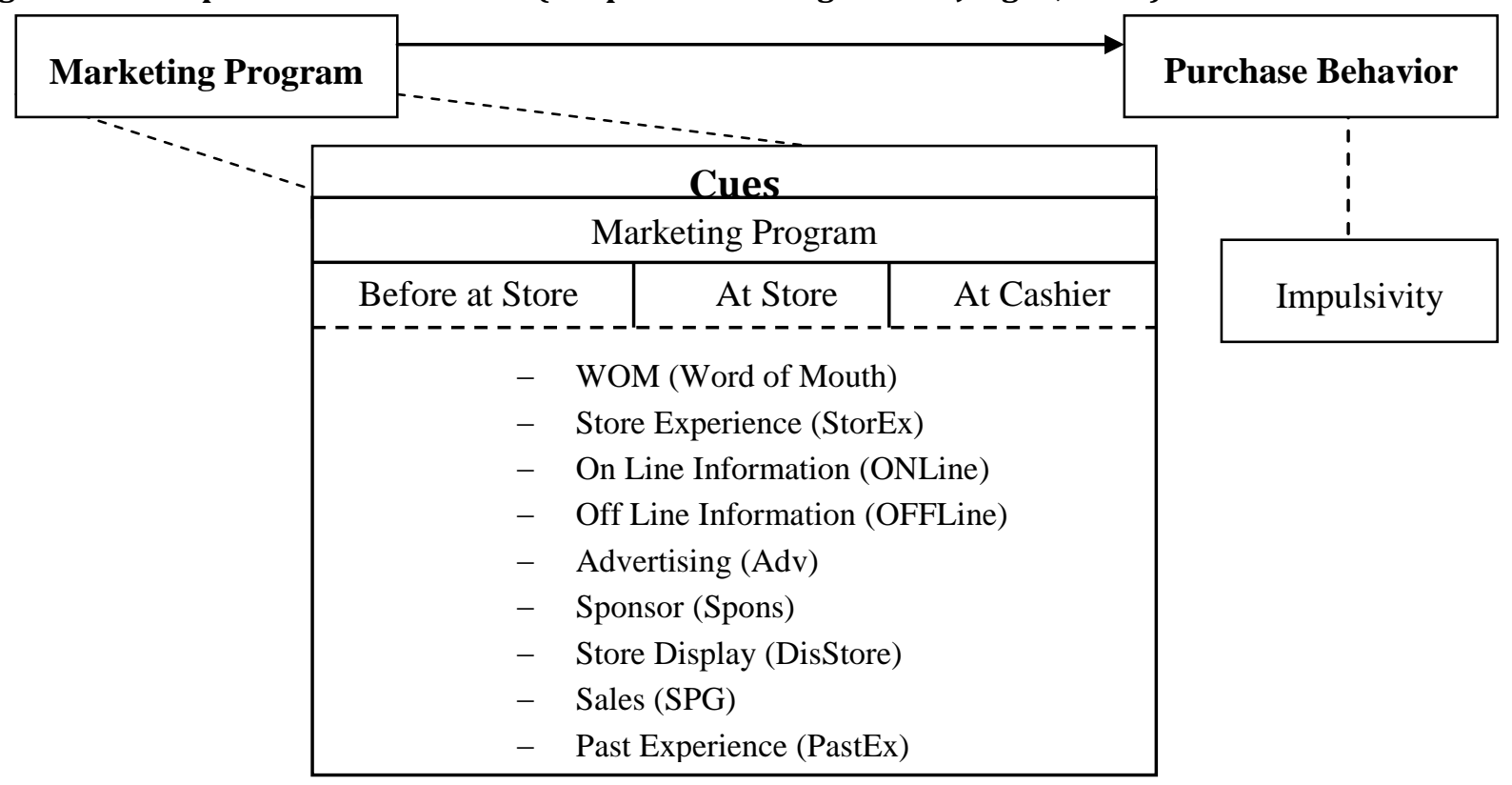

Data collection: Data was collected using observation and questionnaires. The questionnaires were distributed via online and offline media. The offline questionnaires were distributed directly and the online questionnaires distributed by social media (like using facebook, twitter, BBM, etc.), mailing list, and personal email. The survey was established in Indonesia and covers two big cities, which are Semarang, Central Java and Bandung, West Java. In prelimenary research, the author conducted observation for a month around February - March 2013 at some stores in Bandung, West Java on the weekend. Continued with questionnaires distribution with total respondents collected were 105. Multiple regressions are done as methods to analysis in this research. To verify impulsivity, validity and reliability data were conducted use factor analysis (Hair et al., 2010) and showed that 105 respondents are significant impulsivity $(\mathrm{p}=0.000)$.

Table 2: Factor Analysis Results

\begin{tabular}{|c|c|c|c|c|c|c|}
\hline \multirow[b]{2}{*}{ Impulsivity } & \multicolumn{3}{|c|}{ Bartlett's test of sphericity } & \multirow[b]{2}{*}{$\begin{array}{l}\text { Kaisers-Meyer- } \\
\text { Olkin (KMO) }\end{array}$} & \multirow[b]{2}{*}{$\begin{array}{l}\text { Extracted } \\
\text { Variants }\end{array}$} & \multirow[b]{2}{*}{$\begin{array}{l}\text { Factor } \\
\text { Loading }\end{array}$} \\
\hline & df & Sig. & $\begin{array}{l}\text { Approx. chi- } \\
\text { square }\end{array}$ & & & \\
\hline & & & & & & $\begin{array}{l}.854 \\
.742\end{array}$ \\
\hline Impulsive & 10 & 0.000 & 137.520 & 0.736 & 52.322 & $\begin{array}{l}.740 \\
.703 \\
.497\end{array}$ \\
\hline
\end{tabular}

In testing consumer impulsivity here, researcher using five questions from Borrowed scale by Weun et al. (1997). Based on reliability and validity test $(\mathrm{p}=0.000)$ with $\mathrm{KMO}=0,736$; extracted variants $=52.322$; and factor loading are 0,$854 ; 0,742 ; 0,740 ; 0,703$; and $0.497,105$ respondents is significantly confirmed as having impulsivity traits . 


\section{Result and discussion}

Respondent's personal profile: Based on questionnaires of 105 respondents are 57 females. With 77 of respondent's status are not married and 28 are married. Demographics data respondent can be seen in Table 1 below:

Table 3: Demographic profile

\begin{tabular}{rrr}
\hline $\begin{array}{r}\text { Demographic } \\
\text { Factor }\end{array}$ & Variable & No. of Respondent \\
\hline \multirow{2}{*}{ Gender } & Female & 57 \\
& Male & 48 \\
Status & Not Married (Single) & 77 \\
& Married & 28 \\
& $<21$ y.o. & 15 \\
& $21-25$ y.o. & 52 \\
Age & $26-30$ y.o. & 13 \\
& $31-35$ y.o. & 18 \\
& $36-40$ y.o. & 2 \\
& $>40$ y.o. & 5 \\
Education & Under or Senior high school & 16 \\
& Bachelor & 82 \\
& Master & 3 \\
& Doctor/another & 4 \\
& Student & 44 \\
Occupation/Job & Private Sector & 31 \\
& Independent & 2 \\
& PNS (civil servant) & 3 \\
& Another & 25 \\
& <Rp 1.000.000,00 & 25 \\
& Rp 1.000.000 - Rp 2.500.000,00 & 27 \\
& Rp 2.500.000 - Rp 5.000.000,00 & 19 \\
& Rp 5.000.000 - Rp 7.500.000,00 & 19 \\
& Rp 7.500.000 - Rp 10.000.000,00 & 7 \\
& $>$ Rp 10.000.000,00 & 8 \\
\hline
\end{tabular}

From the table above can be seen that the majority of demographic respondents age is around 21-25 years old, the most respondents education was a bachelor, and the most these students with income of about Rp1.000.000, 00-Rp2.500.000, 00.

Based on data from Table 4 above, it can be seen that the most favorite drink are ready to drink tea (TRTD), milk ready to drink (MRTD), instant coffee (CI), crash tea (TC), and fruit juice ready to drink (FRTD). For the most popular consumed brand of milk ready to drink (MRTD) is Ultra milk brand (52 consumers); isotonic ready to drink (IRTD) is Pocari Sweat brand (39 consumers); brand of ready to drink tea (TRTD) is Sosro brand (36 consumers), and fruit juice ready to drink (FRTD) is Buavita brand (34 consumers). Most consumed brand is crash tea (TC) with almost two every month. The average brand consumed per month for the beverage category is at least one brand for each type of beverage category. The highest satisfaction rate is dominated by milk ready to drink (MRTD), tea ready to drink (TRTD), and instant coffee (CI) and followed by the average value of loyalty respectively 5.91; 5.58; and 5.08. For the continuity of beverage consumption from the highest category are the product types such as milk ready to drink (MRTD), ready to drink tea (TRTD), and instant coffee (CI). While the greatest discontinuity for the consumption is liquid supplement product (LS), and powder fruit juice (FJP). Based on analysis, consumer decision based on logical reasoning (think) has higher means than affection (feel) when it comes to impulsivity in beverage. It might be because past experience is the most influential factor, and consumer still considers product benefit in buying beverage 
Table 4: Brand consumed in beverage categorize

\begin{tabular}{|c|c|c|c|c|c|c|c|c|c|c|c|c|c|c|}
\hline \multicolumn{2}{|c|}{ Beverage Categorize } & TRTD & TC & TG & $\mathbf{C P}$ & CI & MRTD & MC & MPA & LS & PS & FJP & IRTD & FRTD \\
\hline \multicolumn{2}{|c|}{ Total Consumed } & 118.00 & 74.00 & 35.00 & 44.00 & 87.00 & 96.00 & 41.00 & 31.00 & 14.00 & 7.00 & 28.00 & 47.00 & 62.00 \\
\hline \multirow{2}{*}{\multicolumn{2}{|c|}{ Mode Brand }} & Sosro & Poci & Mustika ratu & Kapal api & Nescafe & Ultra-milk & Bendera & Anlene & Krating-daeng & Extra joss & Nutri-sari & Pocari sweat & Buavita \\
\hline & & 36 & 25 & 12 & 27 & 17 & 52 & 15 & 21 & 9 & 6 & 25 & 39 & 34 \\
\hline \multirow{6}{*}{$\underset{\Sigma}{\mathbb{E}}$} & $\begin{array}{l}\text { Brand } \\
\text { Consumed/month }\end{array}$ & 1.52 & 1.71 & 1.08 & 1.15 & 1.15 & 1.20 & 1.00 & 1.11 & 1.00 & 1.00 & 1.00 & 1.05 & 1.09 \\
\hline & Satisfaction & 6.56 & 5.11 & 4.38 & 4.09 & 6.07 & 6.73 & 4.83 & 4.57 & 3.21 & 2.68 & 3.85 & 4.93 & 4.99 \\
\hline & Loyalty & 5.08 & 4.67 & 3.62 & 3.60 & 5.58 & 5.91 & 3.89 & 4.02 & 2.62 & 2.02 & 3.28 & 4.07 & 4.15 \\
\hline & Continuity & 5.04 & 4.38 & 3.26 & 3.19 & 4.89 & 5.57 & 3.51 & 3.47 & 2.18 & 1.58 & 2.80 & 3.39 & 4.01 \\
\hline & Feel & 5.29 & 4.89 & 4.30 & 4.18 & 5.36 & 5.50 & 4.29 & 4.64 & 3.37 & 3.08 & 3.86 & 4.68 & 4.60 \\
\hline & Think & 5.56 & 5.50 & 4.99 & 4.87 & 5.90 & 6.09 & 5.08 & 5.58 & 4.74 & 4.34 & 4.73 & 5.46 & 5.21 \\
\hline
\end{tabular}


Impulsivity toward beverage products: Based on validity and reliability test, total of 105 questionnaires are valid and reliable in impulsivity traits (positively having tendency toward impulsivity). Impulsivity in specific is indicated by the total number of product consumed, meaning that on high level of impulsivity, consumer tends to consume product in higher number. Based on regression analysis, impulsivity toward the total amount of beverage products consumed (see Table 5) is not significantly related, but on products like ready to drink tea ( $\mathrm{pTRTD}=0.011)$ and green tea $(\mathrm{pTG}=0.002)$.

Table 5: The Effect of impulsivity toward to Total Number Product consumed for every product beverage.

\begin{tabular}{lllllll}
\hline $\begin{array}{l}\text { Beverage } \\
\text { Categorize }\end{array}$ & $\begin{array}{l}\text { Mean } \\
\text { Square }\end{array}$ & Betha & F & $\begin{array}{l}\text { Std. } \\
\text { Deviation }\end{array}$ & Mean & Sig. \\
\hline TRTD & 239.251 & .248 & 6.750 & 6.11606 & 4.3619 & $.011^{\mathrm{b}}$ \\
TC & 9.285 & -.032 & .103 & 9.44522 & 5.5429 & $.749^{\mathrm{b}}$ \\
TG & 338.096 & .293 & 9.661 & 6.15703 & 6.15703 & $.002^{\mathrm{b}}$ \\
CP & 97.040 & .098 & 1.008 & 9.81278 & 3.5143 & $.318^{\mathrm{b}}$ \\
CI & 541.394 & .165 & 2.888 & 13.81572 & 8.8286 & $.092^{\mathrm{b}}$ \\
MRTD & 74.596 & .094 & .927 & 8.96716 & 5.6857 & $.338^{\mathrm{b}}$ \\
MC & 5.307 & .051 & .272 & 4.39988 & 1.3333 & $.603^{\mathrm{b}}$ \\
MPA & 16.116 & .048 & .238 & 8.19629 & 3.6857 & $.627^{\mathrm{b}}$ \\
LS & 1.506 & -.111 & 1.295 & 1.08012 & .3333 & $.258^{\mathrm{b}}$ \\
PS & 19.005 & -.143 & 2.148 & 2.99058 & .4667 & $.146^{\mathrm{b}}$ \\
FJP & .620 & .045 & .209 & 1.71809 & .6762 & $.649^{\mathrm{b}}$ \\
IRTD & .002 & .002 & .000 & 2.17617 & 1.6286 & $.983^{\mathrm{b}}$ \\
FRTD & .115 & .010 & .011 & 3.24269 & 2.1524 & $.917^{\mathrm{b}}$ \\
\hline
\end{tabular}

Marketing cues influencing impulse buying in beverage products: The regression analysis confirmed that impulsivity is only found in the purchase of green tea (TG) and ready to drink tea (TRTD). This relates to previous result that consumer buys products because of its benefit. Green tea is considered healthy drink with plenty of benefit. Therefore, the subsequent analysis was to find marketing cues (WOM, store experience, online information search, offline information search, advertising, sponsorship, store displays, sales, and experience) that influence that impulsivity on TG and TRTD. Analysis was done using regression and compare means analysis.

Table 6: Means of analysis for marketing cues for beverage categorize buying in initial consideration

\begin{tabular}{|c|c|c|c|c|c|c|c|c|c|c|c|c|c|c|}
\hline & $\begin{array}{r}\text { Beverage } \\
\text { Categorize }\end{array}$ & TRTD & TC & TG & CP & CI & MRTD & MC & MPA & LS & PS & FJP & IRTD & FRTD \\
\hline \multirow{9}{*}{$\begin{array}{l}0 \\
\vdots \\
0 \\
\omega \\
0 \\
0 \\
0 \\
0 \\
0 \\
0 \\
0\end{array}$} & WOM & 5.40 & 4.81 & 4.71 & 4.5 & 5.0 & $\begin{array}{l}5.3 \\
8\end{array}$ & 4.4 & $\begin{array}{l}5.1 \\
2\end{array}$ & 4.23 & 3.88 & 4.02 & 4.54 & 4.4 \\
\hline & StorEx & 3.93 & 3.50 & 3.64 & $\begin{array}{l}3.3 \\
0\end{array}$ & $\begin{array}{l}3.9 \\
2\end{array}$ & $\begin{array}{l}4.1 \\
4\end{array}$ & $\begin{array}{l}3.8 \\
4\end{array}$ & $\begin{array}{l}4.1 \\
5\end{array}$ & 3.33 & 3.29 & 3.45 & 3.43 & $\begin{array}{l}3.8 \\
2\end{array}$ \\
\hline & ONLine & 3.30 & 2.98 & 3.10 & $\begin{array}{l}3.0 \\
0\end{array}$ & $\begin{array}{l}3.2 \\
2\end{array}$ & $\begin{array}{l}3.4 \\
1\end{array}$ & $\begin{array}{l}3.0 \\
6\end{array}$ & $\begin{array}{l}3.2 \\
3\end{array}$ & 2.99 & 2.95 & 3.12 & 3.26 & $\begin{array}{l}3.1 \\
5\end{array}$ \\
\hline & OFFLine & 4.25 & 3.81 & 3.84 & $\begin{array}{l}3.7 \\
2\end{array}$ & $\begin{array}{l}4.0 \\
5\end{array}$ & $\begin{array}{l}4.3 \\
4\end{array}$ & $\begin{array}{l}3.9 \\
7\end{array}$ & $\begin{array}{l}4.0 \\
0\end{array}$ & 3.76 & 3.66 & 3.61 & 3.98 & $\begin{array}{l}3.9 \\
2\end{array}$ \\
\hline & $\mathrm{Adv}$ & 5.11 & 4.35 & 4.70 & $\begin{array}{l}4.1 \\
0\end{array}$ & $\begin{array}{l}4.9 \\
2\end{array}$ & $\begin{array}{l}4.9 \\
0\end{array}$ & $\begin{array}{l}4.3 \\
3\end{array}$ & $\begin{array}{l}4.7 \\
9\end{array}$ & 3.96 & 3.76 & 3.91 & 4.50 & $\begin{array}{l}4.2 \\
4\end{array}$ \\
\hline & Spons & 3.55 & 3.50 & 3.50 & $\begin{array}{l}3.2 \\
8\end{array}$ & $\begin{array}{l}3.6 \\
1\end{array}$ & $\begin{array}{l}3.9 \\
1\end{array}$ & $\begin{array}{l}3.5 \\
7\end{array}$ & $\begin{array}{l}3.9 \\
2\end{array}$ & 3.59 & 3.36 & 3.43 & 3.53 & $\begin{array}{l}3.5 \\
8\end{array}$ \\
\hline & DisStore & 4.66 & 4.38 & 4.38 & $\begin{array}{l}4.1 \\
8\end{array}$ & $\begin{array}{l}4.3 \\
7\end{array}$ & $\begin{array}{l}4.7 \\
0\end{array}$ & $\begin{array}{l}4.3 \\
1\end{array}$ & $\begin{array}{l}4.3 \\
5\end{array}$ & 4.10 & 3.94 & 4.13 & 4.48 & $\begin{array}{l}4.5 \\
0\end{array}$ \\
\hline & SPG & 3.92 & 3.64 & 3.77 & $\begin{array}{l}3.4 \\
5\end{array}$ & $\begin{array}{l}3.7 \\
8\end{array}$ & $\begin{array}{l}3.8 \\
8\end{array}$ & $\begin{array}{l}3.6 \\
7\end{array}$ & $\begin{array}{l}3.9 \\
0\end{array}$ & 3.60 & 3.43 & 3.56 & 3.71 & $\begin{array}{l}3.6 \\
5\end{array}$ \\
\hline & PastEx & 7.15 & 6.34 & 6.34 & $\begin{array}{l}6.1 \\
4 \\
\end{array}$ & $\begin{array}{l}7.1 \\
9 \\
\end{array}$ & $\begin{array}{l}7.4 \\
8 \\
\end{array}$ & $\begin{array}{l}6.2 \\
6 \\
\end{array}$ & $\begin{array}{l}5.9 \\
5 \\
\end{array}$ & 5.50 & 5.19 & 5.54 & 5.92 & $\begin{array}{l}5.9 \\
6\end{array}$ \\
\hline
\end{tabular}


Marketing cues significantly influenced purchase of TG (F=11,689; $p=0,000)$ and TRTD ( $F=18,181 ; 0,000)$ product in initial consideration. Based on the analysis of Post Hoc, Tukey, and Benferoni test for both the product past experience is the most influenced. For Tukey test in TG product, past experience has greater effect than WOM and WOM is more influence than Online Information (PastEx $>$ WOM $>0$ nLine). For TRTD product, WOM has more influence than Sponsorship and Sponsorship has more influence Advertising (WOM $>$ Spons $>$ Adv). Benferoni test shows that for TG product WOM has more influence than online information search and Adv has more influence than online information search (WOM $>0 L<A d v$ ). In TRTD product, marketing cues for WOM has more influence than online information search and sponsorship. However, sponsorship has less influence than Advertising (WOM $>0$ L, Spons $<$ Adv).

Table 7: Means of marketing cues for beverage categorize in active evaluation stage

\begin{tabular}{|c|c|c|c|c|c|c|c|c|c|c|c|c|c|c|}
\hline & $\begin{array}{r}\text { Beverage } \\
\text { Categorize }\end{array}$ & IRTD & TC & TG & CP & CI & TD & MC & MPA & LS & PS & FJP & IRTD & FRTD \\
\hline \multirow{9}{*}{$\begin{array}{l}0 \\
\dot{0} \\
\Delta \\
\omega \\
\pi\end{array}$} & WOM & 52 & 45 & 56 & 21 & 6 & 06 & 20 & 24 & 8 & 1 & 89 & 4.07 & 4.39 \\
\hline & StorEx & 4.13 & 3.64 & 0 & 270 & 4.01 & 42 & 20 & 3.91 & 3 & 2 & 5 & 65 & 79 \\
\hline & ONLine & 3.64 & 3.22 & 3.36 & 3.29 & 3.48 & 3.66 & 342 & 3.39 & 3 & 3 & 27 & 50 & 3.39 \\
\hline & OFFLine & 4.06 & 3.67 & 7 & 380 & 39 & 4.30 & 205 & 6 & 5 & 3.63 & 70 & .78 & 75 \\
\hline & Adv & 4.83 & 4 & 4.49 & 4 & 4.81 & 4.89 & 4.42 & 4.65 & 3.78 & 3.61 & 3.85 & 4.44 & 4.47 \\
\hline & sponis & 3.6 & 3 & 3.46 & 3.30 & 3.66 & 3.90 & 80 & 3.90 & 3.57 & 3.48 & 3.54 & 3.72 & 3.78 \\
\hline & DisStore & 4.5 & 4.23 & 4.19 & 4.32 & 4.47 & 4.58 & 4.31 & 4.30 & 3.85 & 3.74 & 3.79 & 4.25 & 4.33 \\
\hline & SPG & 4.41 & 4.08 & 4.15 & 4.1 & 4.39 & 4.44 & 3.98 & 4.26 & 3.40 & 3.49 & 3.47 & 3.99 & 3.99 \\
\hline & PastEx & 6.51 & 5.82 & 5.81 & 5.74 & 6.62 & 6.51 & 5.89 & 5.57 & 5.13 & 5.00 & 5.22 & 5.50 & 5.53 \\
\hline
\end{tabular}

At the store (during the active evaluation stage); past experience, WOM, advertising display, sales and offline information search are the influencing factors in impulsive buying of beverage. In this active evaluation stage, those marketing cues significantly influence purchasing of TG $(F=6,503 ; p=0,000)$ and TRTD $(F=9,530$; $\mathrm{p}=0,000$ ) product. Based on Post Hoc analysis, Tukey, and Benferoni test for the both, product past experience is the most influence toward purchasing. Tukey and Benferoni test show that purchasing for both of product, past experience is the most influence from all marketing cues $(p=0,000)$, except for WOM information (pTGTukey/Benferoni $=0,62 / 0,89$ ) toward TG product. WOM (means $=4,56$ ) and past experience (means $=5,81$ ) are not significantly different in influencing purchase of TG product. Analysis on TRTD product shows that WOM influences better than Online Information and Sponsorship (WOM>OnLine and Spons). At the active evaluation stage, the customer receives information both internally and externally, as a consideration to buy a beverage categorize. In the evaluation phase (when in a store), marketing cues that influence purchase of beverage categorize are past experience, WOM, advertising, and display store. In this stage, past experience and WOM have similar influence toward impulsive buying.

Table 8: Means of Marketing cues for Beverage Categorize in Moment of Purchase

\begin{tabular}{|c|c|c|c|c|c|c|c|c|c|c|c|c|c|c|}
\hline & $\begin{array}{r}\text { Beverage } \\
\text { Categorize }\end{array}$ & TRTD & TC & TG & CP & CI & ИRTD & MC & MPA & LS & PS & FJP & IRTD & FRTD \\
\hline \multirow{5}{*}{ 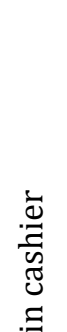 } & WOM & 4.3 & .86 & 3.69 & 380 & 4. & 4.26 & 3.94 & & 2 & 7 & 77 & 2 & 8 \\
\hline & $S$ & & 44 & 3.47 & 3.68 & 38 & & & & 39 & 3.46 & 4 & 0 & 6 \\
\hline & & 3.6 & 3.24 & 3.3 & 3.2 & $3 .{ }^{3}$ & 3.69 & 35 & 3 & 3.30 & 3.2 & 3.45 & 1 & 6 \\
\hline & OFFL in & 4.17 & 3.67 & 37 & $3.7^{7}$ & $4.0 \mathrm{~S}$ & 4. & 3.93 & 48 & 3.59 & 3.44 & 3.70 & 3.69 & 80 \\
\hline & Adv & 4.29 & .85 & . & 3.99 & 4.50 & 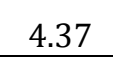 & 4.13 & 4.26 & 3.70 & 3.65 & 3.85 & 4.08 & 4.08 \\
\hline
\end{tabular}




\begin{tabular}{cccccccccccccc}
\hline $\begin{array}{c}\text { Beverage } \\
\text { Categorize }\end{array}$ & TRTD & TC & TG & CP & CI & IRTD & MC & MPA & LS & PS & FJP & IRTD FRTD \\
\hline Spons & 3.65 & 3.37 & 3.37 & 3.33 & 3.58 & 3.73 & 3.60 & 3.72 & 3.56 & 3.47 & 3.45 & 3.56 & 3.56 \\
DisStore & 4.09 & 3.64 & 3.82 & 3.81 & 4.04 & 4.09 & 3.71 & 3.59 & 3.25 & 3.09 & 3.29 & 3.61 & 3.77 \\
SPG & 4.23 & 3.62 & 3.82 & 3.70 & 3.98 & 4.03 & 3.60 & 3.80 & 3.11 & 3.18 & 3.56 & 3.65 & 3.80 \\
PastEx & 5.76 & 5.14 & 4.90 & 5.05 & 5.41 & 5.69 & 5.11 & 4.93 & 4.49 & 4.36 & 4.62 & 4.83 & 4.86 \\
\hline
\end{tabular}

The most influential marketing cues, while waiting for payment in cashier, in purchase of beverage category is also past experience. In moment of purchase, marketing cues are significantly influence purchase of $\mathrm{TG}(\mathrm{F}=$ $3,342 ; \mathrm{p}=0,001)$ and TRTD ( $\mathrm{F}=5,497 ; \mathrm{p}=0,000)$ product. Based on analysis Post Hoc, Tukey, and Benferoni test for the both product, past experience is the most influential toward purchasing. In this TG product, based on Tukey test, past experience is more significantly influence than advertising $(p=0,302)$, store display $(p=0,113)$, and sales $(0,113)$. Whereas with Benferoni test analysis, past experience toward TG product is more significantly influence than StoreEx, online information search, offline information search, and sponsorship. In TRTD product, Tukey and Benferoni test shows that past experience is most significantly influence than other marketing cues ( $\mathrm{p}<0,017)$. In moment at purchase stage (at cashier), DisStore, sales, and Adv have important roles in impulse buying.

\section{Conclusion}

The higher the impulsivity trait of consumers over certain products, they tend to consume those products in higher number. Based on the analysis, this is confirmed in green tea and tea ready to drink category. Therefore, it is concluded that consumer tends to purchase impulsively toward green tea and ready to drink tea. Most preferred brands from those categories are Mustika Ratu for green tea and Sosro for ready to drink tea. Past experience and WOM are the most influencing factors in the impulse buying of green tea and ready to drink tea, at all stage of consumer decision journey. However, on the final stage (moment of purchase), sales, advertising and store display also influence consumer to buy impulsively for those product categories. This research examines many of products from beverage categorize. The future research needs to minimize the products to deeply explore customer experience toward that product. The respondent can be expanded to variation (all age) because from exploratory research found that children have tendency to be impulsive too. Future research can be specifically directed to study green tea and ready to drink tea.

\section{Reference}

Brady, M. K. \& Cronin, J. J. (2001). Some new thoughts on conceptualizing perceived service quality: a hierarchical approach. Journal of Marketing, 65(3), 34-49.

Beatty, S. \& Ferrell, E. (1998). Impulse Buying: Modelling Its Precursors. Journal of Retailing, 74(2), 169-191.

Bughin, J., Doogan, J. \& Jorgen, O. W. (2010). A new way to measure word-of-mouth marketing. McKinsey \& Company. April 2010

Ceballos, L. M. (2009). Analysis of the stimuli of londoners' fashion-oriented impulse buying behaviour. Journal Fashion Marketing in London College of Fashion, 17, 87-97.

Chaudhuri, A. (2006). Emotion and Reason in Consumer Behavior. USA : Elsevier Inc.

Coley, A. \& Burgess, B. (2003). Gender Differences in Cognitive and Affective Impulse Buying. Journal of Fashion Marketing and Management, 7(3), 282-295. Available from: http://www.emeraldinsight.com

Coley, A. (2002.). Affective and cognitive processes involved in impulse buying. MSc study, 1-91.

Crugman, H. (1965). The impact of television advertising: Learning without involvement. Public Opinion Quarterly, 29, 349-356.

Gardner, M. P. \& Rook D. (1988). Effects of Impulse Purchases on Consumers' Affective States. Advances in Consumer Research, 15, 127-130.

Hart, C. \& Davies, M. (1996). The location and merchandising of non-food in supermarkets. International Journal of Retail \& Distribution Management, 24(3), 17-25. 
Herabadi, A. G. (2003). Buying Impulses: A Study on Impulsive Consumption. PDF hosted at the Radboud Repository of the Radboud University Nijmegen

Hair, J. F., Anderson, R. E., Tatham, R. L. \& Black, W. (2005). Multivariate Data Analysis. 6th Edition. PrenticeHall: N.J. (ISBN: 0138948585).

Leibowitz, J. (2010). Retail Practice Rediscovering the Art of Selling. McKinsey Company October 2010.

Likert, R. (1932). A Technique for the Measurement of Attitudes. Archives of Psychology, 140, 5-53.

McLuhan, M. (1964).Understanding media: The extension of man. New York: McGraw Hill.

Mihic, M. \& Kursan, I. (2010). Assessing The Situational Factors and Impulsive Buying Behavior: Market Segmentation Approach. Journal Management, 15(2), 47-66.

Mittal, B. (1989). Must consumer involvement always imply more information search? Advances in Consumer Research, 16, 167-172.

Moon, M. (2011). Non-Traditional Concepts in Brand Management. Media 398: Independent Research Professor Bill Sonnega.

0'ocass, A. (2000). An Assessment of Consumers Product, Purchase Decision, Advertising and Consumption Involvement in Fashion Clothing. Journal of Economic Psychology, 21, 545-576.

Rao, S. \& Laverie, D. A. (2004). Exploring Impulse Purchasing on the Internet. Journal Advances in Consumer Research, 31, 59-66.

Semuel, H. (2006). Dampak Respon Emosi Terhadap Kecenderungan Perilaku Pembelian Impulsif. Jurusan Ekonomi Manajemen, Fakultas Ekonomi - Universitas Kristen Petra p.101-115. http://www.petra.ac.id/ puslit/journals/dir.php?DepartmentID=MAN

Rook, D. \& Fisher, R. (1995). Normative Influences on Impulsive Buying Behavior. Journal of Consumer Research, 22(3), 305-313.

Turley, L. W. \& Miliman, R. E. (2000). Atmospheric Effects on Shopping Behavior: A Review of the Experimental Evidence. Journal of Business Research, 49, 193-211.

Verplanken, B. \& Herabadi, A. (2001). Individual differences in impulse buying tendency: Felling and no thinking. European Journal of Personality, 15, 71-83.

Weun, J. \& Beatty, H. (1997). Normative Influences on Impulsive Buying Behavior. Journal of Customer Research, 22, 305-313.

Zaichkowsky, J. L. (1986). Conceptualizing Involvement. Journal of Advertising, 15(2), 4-14. 